\title{
Micro and macro-level risk factors for extremism and terrorism: Toward a criminology of extremist violence
}

https://doi.org/10.1515/mks-2021-0127

\begin{abstract}
Over the past twenty years, research on political extremism and terrorism has become one of the fastest growing sub-fields within criminology. This rapid growth is reminiscent of the early years of criminology itself, characterized by energy, imagination and creativity but at the same time a specialization struggling to collect and analyze valid data, apply appropriate research methods and develop coherent theoretical frameworks. In this paper, we take stock of these developments by considering a basket of micro- and macro-level risk factors that have been frequently linked to the decision to engage in violent extremism. Following a review of risk factors, we consider major definitional, theoretical, data and methodological challenges and also progress made. Prior criminological research on violent extremism has focused especially on micro-level characteristics and few studies to date have integrated micro and macro determinants to explain extremist outcomes. However, with the growing availability of data, including open-source databases, paired with the application of more sophisticated statistical methods, we expect to see more robust results in the years ahead.
\end{abstract}

Keywords: Risk factors, extremism, terrorism

\section{Introduction}

While there were important criminology contributions to the study of extremism and terrorism prior to 2000 (e.g., Kittrie 1978; Turk 1982; Hamm 1993; Smith 1994), they were relatively uncommon and terrorism was not widely recognized as a major criminological specialization. This situation has changed dramatically in the past two dec-

\footnotetext{
*Corresponding author: Gary LaFree, University of Maryland, LeFrak Hall, Suite 2220, College Park, MD 20742 Maryland, E-Mail: glafree@umd.edu

Anina Schwarzenbach, PhD, University of Maryland; Harvard University, LeFrak Hall, Suite 2220, College Park, MD 20742 Maryland, E-Mail: schwarze@umd.edu
}

ades. Criminology research on terrorism has expanded enormously since 2000 and is now arguably the fastest growing specialization in the field (for reviews, see LaFree \& Ackerman 2009; Forst, Greene \& Lynch 2011; Lum \& Kennedy 2012; Sageman 2014; Freilich \& LaFree 2015;). The reasons for this explosive growth are beyond the scope of this paper but the development was no doubt accelerated in the United States by the coordinated attacks of September 11, 2001 and in Europe by the 2004 Madrid train bombings, the 2005 London bombings, the series of attacks carried out in 2015 in Paris, and the 2016 Berlin Christmas market attacks. Major sources of U.S. funding for behavioral and social science research on terrorism have included the National Memorial Institute for the Prevention of Terrorism and Justice, the National Science Foundation, the National Institute of Justice, the Bureau of Justice Administration and the Department of Homeland Security (LaFree \& Dugan 2016). Funding for social and behavior science research on terrorism has also advanced in Europe (Eder \& Senn 2008), most notably, the European Union's Horizon 2020 initiative (previously called FP7) has released various calls focused on radicalization, violent extremism and terrorism (PROTON 2020).

There are also other important signs that the study of terrorism and political extremism has become a part of the fabric of mainstream criminology. Terrorism research now appears in nearly all mainstream criminology journals; college courses on terrorism and political violence have been added to the curricula of many criminology and criminal justice departments; and a growing number of criminology students are choosing terrorism as a suitable topic for class papers, research topics, theses and dissertations. The American Society of Criminology (ASC) has added a Division on Terrorism and Bias Crime that now has as many members as some long-standing specializations like organized crime and juvenile delinquency. And the ASC, the European Society of Criminology and the Academy of Criminal Justice Studies now routinely feature dozens of papers and panels on terrorism and counter terrorism each year at their annual meetings. While the scientific rigor of this rapidly expanding research literature has been uneven (Silke 2001, 2009; Turk 2004; LaFree 
\& Ackerman 2009), it is clear that research on terrorism and political extremism represents one of the major growth areas in social science scholarship over the past two decades and further, that criminology has figured prominently in these developments.

Despite the rich body of research, scholars have struggled to produce consistent results as to the risk factors that are most important for predicting terrorist attacks. Risk assessment tools in criminology can be traced back at least to the 1920 s, when Ernest Burgess (1936) examined the records of 3,000 former inmates of Illinois prisons to find the variables that distinguished those who committed new crimes while on parole from those who did not. Similar prediction instruments have been developed and applied elsewhere for decades. Over time this collective knowledge has been used by researchers and practitioners to measure vulnerability to violent crime and by criminal justice agencies to make informed decisions about resource allocation, sentencing, release, and parole.

The study of violent political extremism by criminologists has a much more recent history (LaFree and Dugan, 2004, 2009; LaFree and Freilich, 2017) and to this point in time has produced no widely accepted risk assessment tools for policy makers. In a current review, Monahan $(2017,521)$ states simply that there is "scant empirical evidence of the validity of putative risk factors for terrorism beyond the demographically obvious «-by which the author means young men. In fact, a common conclusion (Horgan 2008; Gill 2015; Hafez and Mullins 2015) of more than a decade of research on radicalization is that challenges stemming from the heterogeneity of extremists, the low base rates of offending, and the seemingly prosaic nature of radicalization correlates make it unlikely that research efforts will ever succeed in identifying extremist risk factors.

At the same time, the need for cognate tools to help identify individuals at risk of committing acts of violent political extremism, as well as to make evidence-based decisions about the rehabilitation and reintegration of extremist offenders, has never been greater. According to recent estimates (Blazak 2009; Desmarais et al. 2017; Sarma 2017), the number of groups and individuals adhering to hate-based or extremist ideologies around the world has grown considerably in the last decade, while law enforcement agencies and those who are responsible for administering community-based programs countering violent extremism continue to struggle with limited resources. Prioritizing individuals who are at the highest risk of committing acts of extremist violence is, and will continue to be, crucially important to the success of prevention and counter-terrorism efforts (Kruglanski et al. 2008; Monahan and Skeem 2014; Borum 2015).
In this paper, we take stock of these recent developments by considering the risk factors that best predict the decision to engage in violent political extremism. After LaFree, Dugan and Miller $(2015,13)$, we define extremist violence as »the threatened or actual use of illegal force and violence by non-state actors to attain a political, economic, religious or social goal through fear, coercion or intimidation.« We exclude ordinary criminal violence as well as state terrorism and genocide. Our review is divided into micro- and macro-level risk factors. Because the literature is large and space is limited, we concentrate especially on variables that have gathered the most empirical interest. Following a brief review of risk factors, we consider major definitional, theoretical, data and methodological challenges and also progress made. We conclude by considering implications for theory, future research and policy.

\section{Micro-Level Risk Factors}

In our review of the literature on micro-level terrorism risk factors, we argue that ten variables stand out as especially important. In the sections that follow we briefly review each.

\subsection{Gender}

There is strong and consistent evidence that as with violent crime in general (Gendreau et al. 1996; DeLisi et al. 2013), men are overrepresented as perpetrators of terrorism (Berrebi 2007; LaFree et al. 2018). For example, Bakker (2006) found that only 5 of 242 jihadi terrorists operating in Europe since 2001 (2.1\%) were women. Nevertheless, Bloom (2017) argues that the proportion of women engaging in terrorism is increasing and a growing literature (Zedalis 2004; Speckhard \& Akhmedova 2006; Sjoberg \& Gentry 2011; Bloom 2012; Ortbals \& Poloni-Staudinger 2018) has examined forms of female participation in terrorism.

\subsection{Age}

The well-known criminological assertion that violent crime is associated with youth (Farrington 2003; Sweeten et al. 2013) is also supported in the research literature on terrorist perpetrators. For example, Pape (2005) found that the average age of offenders in his study of suicide terrorists ranged from a low of 21.1 years for the Lebanese Hezbollah to 29.8 years for Chechens. However, there is some 
evidence that the average age of those engaging in terrorism is somewhat older than those engaging in more ordinary forms of crime. In a study of 600 American Islamist extremists, Klausen, Morrill and Libretti (2016) found that the median age for commission of violence was older and occurred across a broader age range than was the case for offenders who had committed more typical violent crimes. Similarly, in a comparison of political extremists and gang members in the United States, Pyrooz, LaFree, Decker and James (2017) found that the average age of adolescent gang members in the United States from the National Longitudinal Survey of Youth was 19 years of age while the average age of U.S. political extremists was 34 years old.

\subsection{Radical Peers}

In a study of nearly 1,500 radical extremists in the United States, LaFree, Jensen, James and Safer-Lichtenstein (2018) found that more than half reported regular contact with radical peers as an important part of their pathway to terrorism. Moreover, the same study found that compared to those who did not report close connections with radical peers, those with radical peers were significantly more likely to have engaged in violent extremism rather than other types of non-violent support for terrorist causes (e. g., financial contributions). While we might expect peer influences to lessen with the growing impact of online radicalization and attacks by lone actors, Gill, Horgan and Deckert (2014) argue that lone actors often establish close relationships, both virtual and face to face, with peers who contribute to their movement toward violence (see also, Spaaij 2011; Klausen 2015).

Jasko, LaFree and Kruglanski (2017) found evidence that the presence of radicalized others (friends but not family members) in the individuals' social network increased their likelihood of using violence for a political cause. Similarly, in a systematic review of protective factors against radical extremism, Lösel et al. (2018) found that contact with non-violent peers had a protective effect against participation in violent extremism.

\subsection{Employment}

The link between various measures of employment and crime is one of the most comprehensively researched areas in criminology and many (but not all) studies conclude that work history is highly correlated with levels of criminal activity (Chiricos 1987; Smith et al. 1992; Uggen 2000).
Similar arguments for a relationship between unemployment and deviant behavior have been applied to discussions of the causes of terrorism (Arnold \& Kennedy 1988; LaFree \& Ackerman 2009). However, thus far, empirical results have been less convincing than the results for unemployment and more ordinary types of crime. Research specifically examining the relationship between employment status and participation in terrorism has found that many members of organizations that use terrorism have jobs. For instance, Hewitt (2003) found that members of the $\mathrm{Ku}$ Klux Klan had a diverse range of positions, from blue-collar laborers to business owners. Similarly, Sageman (2004) concluded that, at the time extremists joined Islamic terrorist groups, the majority of them were students, worked as professionals (e.g., doctors, engineers), or performed semi-skilled labor.

Other research (Krueger \& Malečková 2003; Pape 2005; Piazza 2006; Berrebi 2007; Krueger 2007; Silke 2008) shows that those who participate in terrorist acts are frequently not the poorest members of their societies. An early study by Russell \& Miller (1977) compiled profiles of more than 350 individual terrorist cadres and leaders across 18 different terrorist groups from the years 1966 to 1976. The authors concluded that the majority of these individuals had middle-class backgrounds. Sageman's (2004) survey of 172 members of Islamic terrorist groups found that about three-quarters came from upper- or middle-class backgrounds. Just over one-quarter (27\%) came from working-class or poor backgrounds.

However, some recent research does report a relationship between unemployment and terrorism. In a recent U.S. study, LaFree et al. (2018) found that a lack of stable employment was one of the strongest risk factors for engaging in violent political extremism. The researchers measured lack of stable employment by looking at those who were unemployed as well as those who alternated between periods of employment and unemployment and those who habitually changed careers in the years leading up to their involvement in extremism.

\subsection{Marriage}

The relationship between marital status and lower crime has been supported in criminology research across a variety of methodological approaches (Nettler 1984; Warr 1998; Kirk 2012; Bersani \& Doherty 2013), however its relationship to extremist violence is less clear. In support, Russell \& Miller's (1977) study of terrorist profiles in 18 countries concluded that the typical offender is an unmarried male, and Berrebi (2007) finds evidence suggesting 
married individuals are less likely to participate in Palestinian extremism, however, other scholars have reached different conclusions. For example, three quarters of the jihadi-style terrorists in Sageman's (2008) study were married. In fact, Sageman concluded that those joining jihadi organizations were frequently not fully trusted unless their wives or daughters were sisters of other terrorist perpetrators. Bakker (2006) also reported high levels of marriage among jihadi-style terrorists. Shapiro (2013) found that many Islamist groups encourage intermarriage among group members to build intragroup cohesion and trust. In a recent study Altier, Boyle and Horgan (2019) found that marriage did not act as a protective factor against extremism. In fact, in many cases the spouse was supportive of radical behavior and marriage was found to predict recidivism.

\subsection{Military Service}

Theories of informal social control in criminology argue that military service is a positive turning point that can disrupt criminal trajectories (Bouffard 2003; Bouffard \& Laub 2004), however, research on the link between military service and political violence is less certain. For example, some government reports (DHS 2009; FBI 2008) have detailed the risk of far-right recruitment activities in the U.S. military. Moreover, there is evidence that military training increases rather than diminishes participation in terrorist violence among extremist Islamists (Cooley 2002; Hafez 2008). Indeed, Mendesohn (2011) suggests that individuals with military training are specifically recruited by some extremist groups because of their useful skillset, while those without military training are deemed less desirable.

\subsection{Prior Criminal Activity}

Having a prior criminal record has long been regarded by criminologists as one of the single best predictors of future criminal behavior (Blumstein et al. 1988; Loeber \& Le Blanc 1990) and recent research confirms this relationship for political extremists (Bakker 2006, 2011; Weenink 2015; Bakker \& de Bont 2016; Basra \& Neumann 2016; Boncio 2017; Ljujic \& Weerman 2017; van Leyenhorst \& Andreas 2017; Wolfowicz et al. 2020). Jensen, Seate and James' (2018) analysis of nearly 1,900 individuals who radicalized in the United States shows that pre-radicalization criminal behavior, violent or nonviolent, is the single strongest non-ideological predictor of post-radicalization violence.
The researchers found that individuals on the extremist far-right, especially those motivated by white supremacist views, were substantially more likely to engage in crime prior to radicalizing than were individuals associated with other ideologies. They also found that U.S. extremists rarely specialized in specific crime types and that individuals who engaged in criminal activity before the age of 18 were significantly more likely than non-juvenile offenders to commit acts of violent extremism after radicalizing.

\subsection{Imprisonment}

Closely related to the effects of having a criminal record are the effects of imprisonment. Theory and prior research (Western 2002; Sykes \& Pettit 2014) suggests that spending time in prison is associated with future involvement in violent crime. Some researchers, particularly outside of the United States, have reported connections between time in prison and participation in violent extremism (Cilluffo et al. 2006; Brandon 2009; Neumann 2010; Mulcahy et al. 2013). However, other researchers, particularly in the United States, have been skeptical about a strong link between imprisonment and violent extremism (Jones 2014; Klein, Gruenewald \& Smith 2017). For example, Useem and Clayton $(2009,561)$ conclude that the probability of a terrorist plot being hatched in U.S. prisons is "modest, « owing especially to successes in prison administration to counter prison radicalization and low levels of interest among inmates. Similarly, in a review of prison radicalization in the United States and five other countries, Jones $(2014,74)$ concludes $»$ to date, the radicalization and recruitment of inmates in U.S. prisons has not been a significant problem, « and more generally, that the radicalization of prisoners "is not necessarily a given outcome."

LaFree, Jiang and Porter (2019) examine the link between spending time in prison, being radicalized in prison and the post-release risk of engaging in violent political extremism. Their results show significant increases in post-prison violent extremism for those with prison experience. Moreover, the effects were twice as strong for individuals who also report that they radicalized to an extremist ideology while in prison. Hasisi et al. (2020a) examine recidivism for released terrorism offenders in Jerusalem and find that recidivism to a new terrorism offense increases with the number of prior terrorism-related incarcerations and decreases with the number of additional incarcerations for non-terrorist criminal offenses. 


\subsection{Ideology}

Most of the existing research on political extremism contrasts right- and left-wing ideologies and more recently, radical Islamist ideologies. Hasson et al. (2018) found that left-wing supporters of political causes were more likely to experience empathy than right-wing supporters. Zaal et al. (2011) show that compared to left-wing causes, right-wing causes are linked to a stronger motivation to act regardless of the costs, including support for violent means. Van Hiel et al.'s (2020) meta-analysis supports this line of reasoning, revealing a positive relationship between right-wing ideology and aggressive attitudes and behavior.

Hewitt and Kelley-Moore (2009) and others (Kepel 2006; Lincoln 2010) have highlighted the importance of radical Islamist ideology for increasing lethality of politically motivated violence. Hoffman (2006) details the rise of religious terrorism in the $1990 \mathrm{~s}$ and points out that while religious motives for terrorist attacks have been common, a unique feature of the most recent form of religious terrorism is that the religious aspect of the movement has become the dominant one. In a study of suicide attacks, Henne (2012) finds that the religious ideology of a group greatly increases the number of deaths per attack, controlling for a wide variety of other factors. Juergensmeyer $(2016,2)$ claims that religion is not the underlying cause of political violence, but when groups are able to coopt religion's networks and imagery to recruit others for a political cause it weakens norms against violence. Based on an analysis of world-wide terrorist attacks from 1998 to 2005, Piazza (2009) shows that Islamist terrorist organizations had significantly higher casualty rates than other types of terrorist organizations, controlling for a wide variety of rival explanations. However, Piazza finds that when affiliation with the al Qaeda network is included in quantitative models, Islamist groups were no more likely than non-Islamist groups to commit high casualty terrorist attacks.

\subsection{Mental Illness}

While much research in criminology suggests a positive relationship between previous mental illness and propensity to crime (Cocozza et al. 1978; Steadman \& Felson 1984), the connection between mental illness and terrorism is less certain. Terrorism researchers have studied mental illness for decades, but have thus far failed to reach a consensus on its role in shaping violent political behavior (see Gill \& Corner [2016] for a review). For example, studies by McCauley and Moskalenko (2011) and Nij- boer (2012) conclude that terrorist perpetrators are psychologically stable. However, recent research suggests that while extremists may not exhibit psychopathy, mental illness may indeed be related to extremism as an important causal factor that combines with others to produce pathways to political violence (Gill \& Corner 2016). Indeed, several recent studies find empirical links between mental illness and violent political behavior, especially for unaffiliated loners (Bakker \& de Graaf 2010; Spaaij 2011; Gill et al. 2014; but see Corner et al. [2016] for a cautionary methodological note). In a U.S. study, Gruenewald, Chermak and Freilich (2013) compare homicides committed by farright loner extremists to homicides committed by other types of far-right extremists and found that $40 \%$ of farright loners had a reported history of mental illness compared to only $8 \%$ for other far-rightists. Similarly, in a qualitative study of White supremacists, Simi, Karyn and Bubloz (2016) find that more than half of their sample of $44(57 \%)$ reported suffering from mental illness at the time of their involvement in extremist groups. In a U.S. study of nearly 1,500 political extremists, LaFree et al. (2018) find that controlling for a wide variety of variables, a history of mental illness was significantly related to participation in violent extremism. On balance, existing criminology evidence suggests that mental disorder may be a consistent, although modest, risk factor for the occurrence of violence.

\section{Macro-Level Risk Factors}

In our review of the literature on macro-level terrorism risk factors, we argue that nine variables stand out as especially important. In the sections that follow we briefly review each.

\subsection{Religious, Ethnic and Linguistic Diversity}

Religious motives have long been examined as a cause of terrorism generally, and Islamist terrorism in particular (Stern 2002; Juergensmeyer 2003). Egger and Magni-Berton (2019) use survey data collected in 21 European countries to investigate the link between religious beliefs and terrorism justification among European Muslims. They find that in countries affected by homegrown terrorism, Muslims who adhere to frequent religious practice show high levels of support for terrorism. In a study of world-wide terrorist attacks Piazza and LaFree (2019) find that compared to attacks by non-religious groups, attacks carried out by religious groups produce more casualties, but 
that Islamist religious groups produce fewer causalities than non-Islamist religious groups. Overall, prior research agrees that there are no consistent links between specific types of religions and propensity to engage in terrorism (Krueger \& Maleckova 2003; Kurrild-Klitgaard et al. 2006; Krueger \& Laitin 2008).

Due to the difficulty of distinguishing religious from secular motivations (Pape 2005; Moghadam 2006), other researchers have focused on the relationship between measures of ethno-linguistic fractionalization and ethnic polarization and terrorist attacks. This research reports mixed results. Whereas Kurrild-Klitgaard et al. (2006) find no significant association for measures of ethnic and linguistic fractionalization, Piazza (2008a; 2011) and Foster, Braithwaite and Sobek (2012) find that countries with a more ethnically homogeneous population generate less terrorism. According to Piazza (2012), minority socioeconomic discrimination is a particularly important predictor of terrorist activity. Basuchoudhary and Shughart (2010) show that high levels of ethnic tension are associated with high levels of terrorism. Choi and Piazza (2014) find that domestic terrorism occurs more frequently in countries that exclude certain ethnic groups from political power. Python, Brandsch and Tskhay (2017) investigate the link between ethnic tensions and terrorist attacks and find that areas with high levels of ethnic polarization experience more terrorist attacks.

Taken together, these studies point to links between identity-related measures and terrorist outcomes. However, as Krieger and Meierrieks (2012) note, many of these studies have measurement weaknesses. For example, many studies use time-invariant proxies to measure identity conflict and ethno-demographic inequality (such as indices for ethnic and religious fractionalization) or rely on variables indicating simple proportions (such as the share of the Muslim population). It is unclear to what extent these measures adequately capture tensions rooted in identity conflict, ethno-demographic diversity, or group-specific grievances.

\subsection{Poverty}

Poverty is among the most widely studied, and most controversial, macro-level predictors of terrorism. A substantial part of research questioning whether poor economic conditions explain terrorist activities stems from work carried out in economics and political science and builds on economic strain theory. Findings from several studies show that countries with greater economic growth and stronger welfare measures experience fewer terrorist at- tacks (Burgoon 2006; Freytag et al. 2011; Krieger \& Meierrieks 2012; Choi 2015). Krieger and Meierrieks (2019) show that high levels of income inequality are associated with an increase in domestic terrorism, whereas redistributive efforts reduce terrorist activity.

This research suggests that successful economic development (measured in real GDP per capita) paired with welfare measures that promote income equality and economic opportunity result in less terrorist activity. In a U.S. study, Varaine (2019) finds that the proportion of far-right (versus far-left) terrorists in a given year depends on longterm economic inequality. Most interestingly, Varaine's results suggest that far-right perpetrators mobilized more frequently under periods of long-term economic deprivation, whereas far-left terrorism was more prevalent under improving economic conditions. Gries, Krieger and Meierrieks (2009) apply the Hsiao-Granger method to assess the casual link between domestic terrorism and economic growth based on a sample of seven Western European countries. They find that economic success significantly reduces terrorist violence in three out of the seven countries included in the sample.

Fewer studies confirm the view that terrorist activity increases with economic growth. Using a sample of twelve Western European countries (1994-2007) Caruso and Schneider (2011) for instance find that expected future economic growth is associated with an increase in current terrorist activity. LaFree and Bersani (2014) find that terrorist attacks are particularly prevalent in U.S. counties with low levels of concentrated economic disadvantages. Still other studies find no effect for economic prosperity (Abadie 2006; Kurrild- Klitgaard et al. 2006). Finally, only a handful of studies have tested for a curvilinear relationship between economic conditions and terrorism (Enders, Sandler, \& Gaibulloev 2011).

Summing up, we have little agreement about the extent to which economic measures like poverty increase terrorist attacks. The relationship between measures of poverty and terrorist attacks are significantly reduced once country-specific characteristics and measures of good governance and political freedom are taken into account, suggesting that economic stress may have indirect effects on terrorist attacks (Krueger \& Maleckova 2003; Kurrild-Klitgaard et al. 2006; Freytag et al. 2008; Krueger \& Laitin 2008; Basuchoudhary \& Shughart 2010; Plümper \& Neumayer 2010). 


\subsection{Democracy}

A good deal of research has investigated the extent to which regime type and level of democratization of a country correlates with terrorism (Abadie 2006; Wade \& Reiter 2007; Savun \& Philips 2009; Chenoweth 2010; Wilson \& Piazza 2013; Gaibulloev et al. 2017). These studies operationalize country-level democracy in different ways but generally account for some or all of the following elements: electoral processes, civil and political freedoms, levels of political participation and competition. Despite the fact that the connection between democracy and terrorism has been analyzed frequently, the true effect of democracy on terrorist attacks remains uncertain. Research has suggested both positive (Krueger \& Maleckova 2003; Burgoon 2006; Kurrild-Klitgaard et al. 2006; Krueger \& Laitin 2008; Piazza 2008b; Basuchoudhary \& Shughart 2010; Chenoweth 2010; Plümper \& Neumayer 2010; Goldstone et al. 2010; Kriger \& Meierrieks 2011; Piazza 2013; Wilson \& Piazza 2013; Bell 2017) and negative relationships (Li 2005; Masters \& Hoen 2012; Simpson 2014) between measures of democracy and terrorism, with some studies finding no linkage between the two (Piazza 2008a). Still other research (Abadie 2006; Gaibulloev et al. 2017) points to a curvilinear, and more specifically to an inverted U-shaped relationship between different measures of democracy, such as political freedom, and terrorism. These results confirm findings by other research (Chenoweth 2013; Piazza 2013) showing that as regimes transition toward more democratic systems, they experience high levels of political violence.

More recently, Schwarzenbach and LaFree (2020) have taken a "whole of government « approach to the study of terrorism, analyzing the effects of different dimensions of state legitimacy on terrorist outcomes. This research finds an inverted U-shaped relationship between measures indicating high democratic standards and domestic terrorist attacks. The authors also find that domestic terrorist attacks are particularly frequent in times where government activities are directed towards outcomes which increase the overall wellbeing of the population.

\subsection{Weak States}

A good deal of research has examined connections between terrorist attacks and failed or weak states (LaFree et al. 2008; Piazza 2008). In general, weak or failing states are defined as those that experience prolonged periods of civil conflict and war, political crises, and massive human rights violations (Esty et al. 1995, 1). Most of this research is rooted in political science theories and finds that failed or weak states provide an ideal environment for terrorist organizations. A politically unstable state generally coincides with high levels of exposure to both national and international terrorism (Lai 2007; LaFree et al. 2008; Wilkenfeld 2008; Savun \& Phillips 2009; Bell 2017). Nonetheless, not all research is supportive of this association (Eubank \& Weinberg 2001; Piazza 2008).

Newman (2007) argues that weak or failed state measures do not provide us with a comprehensive understanding of the causes of terrorism, nor is the weak and failed state condition sufficient for explaining the presence of terrorist groups in the first place. Most importantly, the weak state argument fails to explain why terrorism also occurs in states not classified as weak or failing.

\subsection{Group Structure and Dynamics}

Group structure and dynamics have been extensively studied in social and organizational psychology, but so far have rarely been applied in criminological research on terrorism. Studies on the relationship between group characteristics and terrorist activity (Post et al. 2002; Hoffman 2006; Klein, Gruenewald \& Smith 2016; Marsden 2016) find that group attributes, dynamics and cohesion have important effects on the decision to engage in terrorist activities. Asal and Rethemeyer (2008) find that larger and more socially networked groups are particularly prone to adopt violent tactics. Blomberg, Gaibulloev and Sandler (2011) show that the longevity of terrorist groups is determined by ideology, tactics and base of operations. Thus, larger organizations that diversify their attack modes and base their operations in the Middle East or Africa had greater longevity. In a study of world-wide terrorism, Piazza and LaFree (2019) find that terrorist groups with links to transnational diasporas have low casualty levels.

\subsection{Responses to Terrorism}

A growing area of macro-level research has analyzed the impact on terrorism of preventive and repressive government responses. This research most often builds on rational choice theories whereby terrorist perpetrators weigh the costs and benefits of terrorist attacks, based in part on governmental responses (Dugan \& Chenoweth 2012). Much of this research shows that repressive counterterrorism measures may induce backlash effects and are likely to be followed by periods of increased political violence 
(LaFree, Dugan \& Korte 2009; Chenoweth \& Dugan 2012; Argomaniz \& Vidal-Diez 2015). At the same time, other research suggests that an increase of counterterrorism spending, proactive policies and specific target hardening measures may reduce the incidence and lethality of terrorism (Gil-Alana \& Barros 2010; Danzell \& Zidek 2013). However, most of this research does not account for the possibility that different terrorist groups may respond differently to specific government measures (Krieger \& Meierrieks 2012).

In a recent study, Jugl et al. (2020) have performed a meta-analysis of nine psychological prevention programs against radicalization and extremism. The authors find that overall, the programs had a significant mean positive effect on behavioral and psychological outcomes related to extremism, such as extremist attitudes. Although these results are promising, the limited number of studies included in the analysis prevents further generalization.

\subsection{Population Size}

Population size is one of the best supported macro-level predictors of terrorist attacks. Most prior studies find that compared to countries with fewer people, more populous countries experience higher levels of terrorist activity (Krueger \& Maleckova 2003; Burgoon 2006; Lai 2007; Plümper \& Neumayer 2010; Krueger \& Laitin 2008; Piazza 2008 b; Coccia 2018). Some scholars (Freytag et al. 2011; Ezcurra \& Palacios 2016) argue that large populations correlate with high levels of demographic stress which in turn fosters conflict and violence. By contrast, Krieger and Meierrieks (2012) claim that terrorist attacks may simply be more likely to occur in large countries.

\subsection{Globalization}

Bove and Böhmelt (2016) and others (Azam \& Thelen 2008; Blomberg \& Hess 2008; Brockhoff, Krieger \& Meierrieks 2015) assess effects of globalization on terrorist attacks through increased migration flows, international cooperation and advances in educational attainment. Several studies (Bove \& Böhmelt 2016; Marbach \& Ropers 2018; Forrester et al. 2019; McAlexander 2020) have analyzed the relationship between immigration and political violence, finding mixed results. Bove and Böhmelt (2016) find that migrant inflows generally reduce the number of terrorist attacks. However, terrorism does diffuse to other countries through migrants leaving from terrorist-prone states. Choi and Salehyan's (2013) show that countries with many refugees are more likely to experience both domestic and international terrorism. However, drawing on bilateral migration data for 170 countries from 1990 to 2015, Forrester et al. (2019) find no evidence in support of the thesis that immigrants import terrorism.

Research has also explored the effect of international political cooperation and terrorism. Not surprisingly, most research finds that involvement in civil and interstate conflicts, a condition that is difficult to separate from terrorism, is significantly associated with an increase in political violence (Lai 2007; Piazza 2008). Blomberg and Hess (2008) and others (Azam \& Delacroix 2006; Azam \& Thelen 2008) conclude that aid reception and membership in international organizations, such as the World Trade Organization, reduce terrorism. By contrast, Plümper and Neumayer (2010) conclude the opposite, providing justification for further research. Finally, some research has suggested that higher educational attainment discourages terrorism (Azam \& Thelen 2008), while other studies (Kurrild-Klitgaard et al. 2006; Freytag et al. 2008) do not support this conclusion.

The research exploring the link between globalization and terrorism faces the challenge of operationalizing key constructs like modernization and international cooperation, which limits the comparability of results. For example, research exploring links between global economic variables and terrorism, using trade openness and economic integration as proxies, find mixed results (Li \& Schaub, 2004; Burgoon 2006; Kurrild-Klitgaard et al. 2006; Blomberg \& Hess 2008 a; Freytag et al. 2008).

Except for involvement in civil and interstate conflict, we thus conclude that at present there is no satisfactory answer as to whether globalization affects the number of terrorist attacks. Moreover, future research should test Bjorgo's (2005) argument that globalization and other structural factors are associated with diverse social outcomes which frequently interrelate with each other and of which terrorism is just one.

\subsection{Contagion}

Recent studies have looked at the effect of spatial and temporal features on terrorism, exploring patterns of contagion (Cliff 2013; LaFree, Xie \& Matanock 2017; White, Ruggeri \& Porter 2019). Onat (2019) finds that terrorism is concentrated both geographically and temporally (see also Nemeth, Mauslein \& Stapley 2014; Kluch \& Vaux 2016) and Lai (2007) argues that past terrorist attacks are strong predictors of future attacks. Indeed, terrorist attacks are often concentrated in »hotspots« (Enders \& Sandler 2005; Piaz- 
za 2007; Porter \& White 2010; Behlendorf, LaFree \& Legault, 2012; Perry 2020).

Multiple studies (Lai 2007; Braithwaite \& Li 2007; Plümper and Neumayer 2010; Cliff \& First 2013; Python et al. 2016) provide evidence for »spillover« effects of terrorism: diffusion mechanisms that increase terrorist activities in places that are spatially and temporally proximate to terrorist hotspots. However, recent research by LaFree, Xie \& Matanock (2018) suggests that this type of contagion is relatively rare. Finally, several studies argue that there is an association between high temperature and terrorist activity (Price \& Elu 2016; Craig, Overbeek \& Niedbala 2019).

Spatial and temporal patterns reveal interesting associations with different forms of terrorist violence (Hasisi et al. 2020b). However, the research in this field is still relatively uncommon, preventing final conclusions on the influence of spatio-temporal dependencies (Ezcurra \& Palacios 2016).

\section{Taking Stock: Progress and Challenges}

In the past two decades we have arguably moved faster and farther toward a criminology of terrorism than we have in any other substantive area within criminology. But not surprisingly, given how recent the sustained interest in this area has been, we find many studies where data are weak or nonexistent, rigorous methods are lacking, and results are disconnected from theoretical frameworks. In many ways, contemporary criminological research on terrorism resembles the early years of criminology itself, characterized by a good deal of energy and imagination but at the same time a specialization facing differing definitions of key concepts and struggling to produce sophisticated theoretical explanations, valid empirical data, and cutting-edge methods. In this section we briefly summarize progress and continuing challenges with terrorism definitions, theoretical conceptualization, data, and methods.

\subsection{Terrorism Definitions}

Because definitions of terrorism vary, and because terrorism has a strong political dimension, not all individuals or governments agree on exactly what constitutes terrorism. While the old bromide that »one man's terrorist is another man's freedom fighter « is simplistic it nevertheless does reflect an underlying challenge in providing a universally accepted definition of terrorism. In a recent review, Easson and Schmid (2011) identify 260 different definitions of terrorism. The fact that there is no universally accepted definition of terrorism means that researchers have to make difficult decisions about how to conceptualize and count it. The lack of a shared definition of terrorism also limits the ability of researchers comparing different data sources to generalize their findings.

However, while the lack of a universal definition of terrorism raises difficulties, the same deficiency also offers an unexpected advantage. One of the biggest challenges of collecting and analyzing cross-national data on more ordinary crimes like homicide and burglary is that while every country considers these activities to be criminal, each country has its own legal definitions (Nivette 2011; LaFree 2021). Because no such conventions exist for terrorism, researchers are free to develop a single uniform definition and apply it to all countries of the world. For example, the definition of terrorism adopted by the creators of the Global Terrorism Database (LaFree et al. 2015) can in principal be applied to all countries-something that is quite difficult to do with more ordinary crimes like homicide or burglary where total counts based on varying legal definitions are likely to be inconsistent.

\subsection{Theoretical Challenges}

A common criticism of criminological research on terrorism is that it is under theorized (LaFree \& Freilich 2017). Indeed, in comparison to studies of ordinary crime, mainstream criminological perspectives like strain, social control, learning and situational have been applied far less frequently to the study of extremist violence (LaFree \& Yanez forth.). However, a range of developments have gradually changed this situation in the past two decades. First, Agnew (2007) has argued that collective strains increase the likelihood of terrorism because they increase negative emotions, reduce social and self-controls and the ability to cope through legal channels, foster the social learning of terrorism, strengthen group ties, and contribute to the formation of terrorist groups. These strains increase the likelihood of terrorism by leading to negative emotional states and traits such as frustration and humiliation and reducing the effectiveness of social control through legal channels. Several recent studies (Nivette et al. 2017; Holt et al. 2018) have built on general strain theory.

Second, social learning perspectives emphasize the impact of social influences on crime, particularly peers (Warr \& Stafford 1991; Akers 2009). Within this context, there is an evolving learning process that involves the transmission of behaviors through imitation, modeling, 
conditioning, and reinforcement (Akers 2009). Peer influences can occur through mechanisms such as fear of ridicule or the desire for loyalty, which produce compliance and opportunities for status enhancement (e.g., acceptance, reward systems; Warr 2002). Individuals are influenced according to the frequency, intensity, duration, and priority of their relationships with others, which in turn help create and mold definitions of behavior (Akers 2009). Recently, proponents of social learning theory explanations have applied this perspective to understand extremist violence (Akers \& Silverman 2004; Akins \& Winfree 2017; Mills et al. 2019), arguing that individuals learn to be terrorists in the same way that they learn other types of criminal and noncriminal behavior.

Third, social control perspectives presuppose that the motivation to offend is ubiquitous, but that individuals refrain from offending if they have strong bonds to conventional society, important sources of which are employment, marriage and education (Hirschi 1969; Laub \& Sampson 1993). In a study of U.S. extremists, LaFree et al. (2018) show that lack of stable employment, a common measure of social control, is consistently related to violent extremism. Recent research by Becker (2019) concludes that being married decreases the chances of engaging in violent ideologically motivated behavior. Additionally, Becker finds that a more developed set of radical beliefs - indicative of a weak belief in the moral authority and rightness of prosocial institutions - is significantly related to involvement in violent ideologically motivated behavior.

Fourth, a growing number of researchers studying terrorism have turned to situational perspectives to help explain extremist violence (Freilich et al. 2019). Proponents (Hsu et al. 2018; Marchment \& Gill 2019) argue that terrorist attacks increase when the situations favoring attacks increase. For example, Perry et al. (2017) claim that situational counter terrorism measures may have beneficial effects that may even diffuse to other crime situations. Wikstrom's (2014) situational action theory of terrorism is closely related. Wikstrom \& Bouhana (2017) make the case that theoretical explanations of terrorism and radicalization must be mechanism-based and integrated at all levels of analysis.

Fifth, studies investigating the link between social identity, group-specific grievances and terrorist violence build on assumptions that resonate with the conflict theoretical perspective (Piazza 2008, 2011; Basuchoudhary \& Shughart 2010). Conflict theorists assume that conflict is a natural part of human social interaction (Breen 2014, 1), assert that crime is explained through deep-seated societal divisions, and hold that class conflict and social and economic inequality promote antisocial behavior. The ruling class exerts power over the lower class and protects its vested interest through criminal law and the justice system (Morin 2014). Studies have applied this perspective to research on terrorist outcomes using various proxies to measure identity conflicts and socio-economic inequalities (Kurrild-Klitgaard et al. 2006; Piazza 2008b, 2011). As these proxy measures get more accurate over time, conflict theory is likely to provide more powerful insights on how inequality and social stratification relate to terrorist outcomes (Krieger \& Meierrieks 2012).

Sixth, in their classic work, Durkheim and Merton posit that modernization is often accompanied by rapid and disruptive social change (Bernburg 2020). Socially disorganized societies are characterized by anomie, a widespread lack of commitment to shared values, standards, and rules which triggers individual distress and deviant behavior. Several scholars (Lai 2007; Plümper and Neumayer 2010) have found that modernization and its correlates - political alliances, economic globalization and increased migration flows - are associated with increased terrorist attacks. Anomie can result in the weakening of traditional institutions, particularly with regard to economic wellbeing. For example, conditions of anomie have been studied to better understand connections between terrorism and weak or failing states (Wilkenfeld 2008; LaFree et al. 2008; Savun \& Phillips 2009; Bell 2017;). Anomie provides for particularly powerful explanations of national-level differences in crimes (Bernburg 2019). As such, it allows for the analysis of links between terrorism and economic inequality, materialistic values, institutional dominance of market-driven processes and values, and rapid social change.

Seventh, procedural justice raises concern about the fairness of the processes by which individuals and institutions in positions of authority make decisions (Bennett, Hine \& Mazerolle 2018). Tyler (1990) argues that in their judgement about the legitimacy of the state and its institutions, citizens rely heavily on the perceived fairness of formal procedures and processes. A robust body of criminological research concludes that in the encounter with representatives of state authority, citizens care more about how they are treated (procedural fairness) than about the specific outcomes of encounters (Hough et al. 2010; Murphy, Bradford \& Jackson 2016). Chenoweth (2010) and others (Wilson \& Piazza 2013; Gaibulloev et al. 2017) have studied the relationship between measures of fair and just procedures and terrorism by researching the extent to which high levels of democratization prevent terrorism. Fewer studies have investigated whether procedural fairness matters for individual attitudes toward extremist violence (Schwarzenbach \& Baier 2020).

Finally, environmental criminology has been adopted as a framework for understanding the impact of spatial 
and temporal features on terrorist violence. According to this perspective, local geography, physical location and timing influence the occurrence and distribution of crime. Influential concepts stemming from environmental criminology, such as the criminology of place that analyses crime rates at specific places over time as well as approaches that investigate contagion effects of crime have inspired the work of scholars in terrorism research (Behlendorf et al. 2012; Kluch \& Vaux 2016; Onat 2019). The analysis of complex patterns of contagion typically requires detailed information and large datasets, which likely explains why this research has long been underdeveloped. Studies building on environmental criminological approaches have become more prominent with the increased sophistication and internationalization of databases recording extremist and terrorist violence.

To summarize, we have seen a growing number of studies that rely on criminological theories to help understand terrorism. Still, it seems fair to say that to this point in time, mainstream criminological theories have been less helpful in explaining terrorism than more common types of crime. Whether this is a feature of the inapplicability of existing criminology theories to the phenomenon of terrorism, or simply a lag in applying theoretical models to a type of criminal behavior that was until recently neglected, remains to be seen.

\subsection{Terrorism Data}

Compared to studies of ordinary crime research on terrorism and political violence has faced unique data challenges. Traditionally, criminologists have relied on three main data sources: official data are collected from the criminal justice system (most often the police), victimization surveys are based on interviews with crime victims and self-report surveys are based on interviews with crime perpetrators. None of these data sources are routinely available for the study of terrorism. Because few countries collect official data on terrorism and many of those convicted of terrorism-related offenses are instead prosecuted for ordinary crimes like homicide and money laundering, official data on terrorism is often unavailable. Victimization surveys are of little value in the case of terrorist attacks where victims are randomly selected, have little information about the perpetrators or do not survive the attacks. Self-report data are difficult in the case of terrorism where most perpetrators actively avoid researchers.

However, the study of terrorism has one distinct data advantage compared to the study of more common types of crime like homicide or robbery: because of the compel- ling interest that terrorist perpetrators have in media attention, open-source information collected from the print and electronic media may be uniquely useful in the study of terrorism. Terrorism expert Brian Jenkins (1975) declared that »terrorism is theatre« and explained how terrorist attacks are often carefully choreographed to attract the attention of the electronic media and the international press. The fact that terrorists are specifically seeking attention through the media means that compared to coverage of more common crimes, coverage of terrorism is likely to be more complete. Thus, while few researchers would suggest tracking burglary or fraud rates by studying electronic and print media, it seems more defensible to track terrorist attacks in this way. For example, it is hard to imagine that it is possible today for an aerial hijacking or politically motivated assassination-even in remote parts of the worldto completely elude attention of the global media.

As a result of these characteristics of terrorism, open-source databases on terrorism have flourished in the past few decades (for a review, see LaFree 2019). In fact, much of the research reviewed in this article has been based on open-source data on terrorism and political extremism. As a result, cross-national criminological research on terrorism is far more inclusive in terms of the range of countries studied by researchers than has been the case for studies of more common types of crime like homicide. While most cross-national crime research has been limited to a small number of highly industrialized western-style democracies (LaFree 1999; Nivette 2011) open-source terrorism databases offer coverage for all countries.

\subsection{Methodological Challenges}

Research on terrorism has frequently been criticized for a lack of strong research methods (Schmid \& Jongman 1988; Victoroff 2005). For example, in studies from the early 2000 s Silke (2001) and Lum et al. (2006) both found that only three percent of terrorism studies employed statistical analyses. This was much lower compared to the related fields of forensic psychology and criminology. However, the methodological sophistication of terrorism research has increased greatly in the past two decades. For example, in a 2012 special issue of the Journal of Quantitative Criminology (LaFree \& Freilich 2012), researchers examined the geospatial distribution of terrorist »hot spots« (LaFree et al. 2012; Behlendorf etal.2012; Braithwaite \& Johnson 2012;); group-based trajectory analysis (Miller 2012; Morris \& Slocum 2012); case control methods (Gruenewald \& Pridemore 2012); multi-level modeling (Johnson 2012); and selectivity bias (Chermak, Freilich \& Suttmoeller 2013). 
It appears that methodological innovations are continuing. Based on a sample of nearly 3,500 articles in nine leading terrorism journals, Schuurman (2020) concludes that the use of more sophisticated data collection and analytic methods have become even more common from 2007 to 2016. A 2020 special issue of the Journal of Quantitative Criminology (LaFree et al. 2020) includes articles based on random effects meta-analysis of risk and protective factors for radicalization (Wolfowicz et al. 2020); proportional hazards regression models (Hasisi et al. 2020a); coarsened exact matching (LaFree et al. 2020); proximity coefficients (Corner \& Gill 2020); analysis of non-linear pathways (Semmelbeck \& Besaw 2020); separable temporal exponential random graph models (McMillan et al. 2020); micro-level spatial analysis (Perry 2020); analysis of distance-decay patterns (Hasisi et al. 2020b); risk-terrain modelling (Marchment \& Gill 2020); Granger causality and autoregressive Poisson analyses (Carson et al. 2020); and hierarchical logistic regression (Varaine 2020). Of course there is still much room for improvement. Even when researchers use the same dataset for their measure of terrorism, they often use different research designs and model specifications, making comparisons difficult. With few exceptions (Python et al. 2016), studies rarely account for spatial dynamics and temporal dependencies. Moreover, researchers have struggled to develop suitable proxy measures for important concepts like globalization, inequality and deprivation.

\section{Conclusions}

Terrorist violence is a form of crime and thus falls naturally within the domain of criminology (LaFree \& Dugan 2004; Clarke \& Newman 2006). However, compared to more common types of crime it also has unique characteristics, including in particular the fact that many who engage in terrorism see themselves as altruists rather than criminals. Over the past two decades, criminological research on terrorism has become a major specialization. Much of this work is interdisciplinary and cross-national and builds on a wide array of theoretical perspectives. We have reviewed some of the micro- and macro-level measures that have been most useful for explaining the etiology of terrorism. We have also explored the extent to which criminological perspectives and research methods have been applied to help understand the phenomenon of terrorism.

Most research on violent extremism takes a restricted view of the variables that make individuals vulnerable to extremist narratives and behaviors. In this review we have distinguished between micro (individual) and macro (societal) risk factors. Early research on violent political extre- mism has focused especially on micro-level characteristics (Horgan 2008; Kruglanski et al. 2009; Schmid 2014). While important, these studies typically do not integrate the macro-level variables that help drive extremist outcomes. As we have seen, except for population size, which is consistently found to be associated with high numbers of terrorist attacks, studies generally find mixed results for the influence of other common macro-level predictors on terrorism. However, with the growing availability of data, including open-source databases, paired with the application of more sophisticated statistical methods, we expect to see more robust results in the years ahead. We foresee that future research will produce more accurate estimates for terrorist risk factors, accounting for the complex interdependencies between spatial and temporal measures and terrorist violence.

Criminological research on violent crime has made progress in developing risk assessment tools for offending in large part because studies of violent criminal behavior often incorporate multiple levels of analysis. Thus, research on offending not only explores micro-level correlates, such as age, gender, race, and socioeconomic status (Sampson \& Lauritsen 1994; Lattimore, Visher \& Linster 1995; Farrington 1998; Ahonen, Loeber, \& Pardini 2016) but also macro-level structural conditions (e.g., poverty, inequality, mobility) that create permissive or restrictive environments for crime (Shaw \& McKay 1942; Sampson, Raudenbush \& Earls 1997). Similarly, popular risk assessment tools in criminology, such as the Level of Service Inventory-Revised (LSI-R), take a multi-level approach to establishing the likelihood of recidivism among offenders (Andrews \& Bonta 2000). The key to a risk-based understanding of violent extremism may well lie in the exploration and integration of variables found at different levels of abstraction.

\section{References}

Abadie, A. (2006). Poverty, political freedom, and the roots of terrorism. American Economic Review, 96(2), 50-56.

Agnew, R. (2010). A general strain theory of terrorism. Theoretical Criminology, 14(2), 131-153.

Ahonen L., Loeber R. \& Pardini D. (2016). The prediction of young homicide and violent offenders. Justice Quarterly, 33(7),1265-91.

Akers, R. L. (2009). Social Learning and Social Structure: A General Theory of Crime and Deviance. New Brunswick, NJ: Transaction.

Akers, R. L., \& Silverman, A. L. (2004). Toward a social learning model of violence and terrorism. In: Zahn, M. A., Brownstein, H. H., and Jackson, S.L. (eds.). Violence: From Theory to Research, Cincinnati, $\mathrm{OH}$ : LexisNexis-Anderson pp. 19-36.

Akins, J.K. \& Winfree, T. (2017). Social learning theory and becoming a terrorist: New challenges for a general theory. In LaFree, G., \& 
Freilich, J.D. (eds.). The Handbook of the Criminology of Terrorism. West Sussex, UK: Wiley, pp. 133-149.

Altier, M.B., Boyle, E.L., \& Horgan, J.G. (2019). Returning to the fight: an empirical analysis of terrorist reengagement and recidivism. Terrorism and Political Violence, 18, 1-25.

Andrews, D. A., \& Bonta, J. (2000). The level of service inventory-revised. Toronto, Canada: Multi-Health Systems.

Argomaniz, J., \& Vidal-Diez, A. (2015). Examining deterrence and backlash effects in counter-terrorism: The case of ETA. Terrorism and Political Violence, 27(1), 160-181.

Arnold, T.E., \& Kennedy, M. (1988). Think About Terrorism: The New Warfare. New York: Walker.

Asal, V., \& Rethemeyer, R. K. (2008). Dilettantes, Ideologues, and the Weak: Terrorists Who Don't Kill. Conflict Management and Peace Science ,25(3), 244-263.

Azam, JP, \& Delacroix, A. (2006). Aid and the delegated fight against terrorism. Review of Development Economics, 10(2), 330-44.

Azam, J.P., \& Thelen, V. (2008). The roles of foreign aid and education in the war on terror. Public Choice, 135(3-4), 375-97.

Bakker, E. (2006). Jihadi Terrorists in Europe, their Characteristics and the Circumstances in which They Joined the Jihad: An Exploratory Study. The Hague: Clingendael Inst.

Bakker, E., \& De Bont, R. (2016). Belgian and Dutch jihadist foreign fighters (2012-2015): Characteristics, motivations, and roles in the War in Syria and Iraq. Small Wars and Insurgencies, 27(5), 837-857.

Basra, R., \& Neumann, P. R. (2016). Criminal pasts, terrorist futures: European jihadists and the new crime-terror nexus. Perspectives on Terrorism, 10(6), 25-40.

Basuchoudhary, A., \& Shughart, W. F. (2010). On ethnic conflict and the origins of transnational terrorism. Defence and Peace Economics, 21(1), 65-87.

Becker, M. (2019). When extremists become violent: examining the association between social control, social learning, and engagement in violent extremism. Studies in Conflict and Terrorism, 11, 1-21.

Behlendorf, B., LaFree, G., \& Legault, R. (2012). Microcycles of Violence: Evidence from Terrorist Attacks by ETA and the FMLN. Journal of Quantitative Criminology, 28(1), 49-75.

Bell, M. C. (2017). Police reform and the dismantling of legal cynicism. The Yale Law Journal 126, 2054-2150.

Bennett, S., Hine, L., \& Mazerolle, L. (2018). Procedural Justice. Oxford Bibliographies. https://www.oxfordbibliographies.com/ view/document/obo-9780195396607/obo-97801953966070241.xml

Bernburg, J. G. (2019). Anomie theory. Oxford Research Encyclopedia of Criminology and Criminal Justice. https://oxfordre.com/crim inology/view/10.1093/acrefore/9780190264079.001.0001/ acrefore-9780190264079-e-244

Berrebi, C. (2007). Evidence about the link between education, poverty and terrorism among Palestinians. Peace Economics, Peace Science and Public Policy, 13, 1-36.

Bersani, B. E., \& Doherty, E. E. (2013). When the ties that bind unwind: Examining the enduring and situational processes of change behind the marriage effect. Criminology, 51, 399-433.

Bjorgo, T. (eds.) (2005). Root Causes of Terrorism. Myths, Reality and Ways Forward. Abingdon: Routledge, pp.3-4.

Blazak. R. (2009). The prison hate machine. Criminology and Public Policy 8(3), 633-640.
Blomberg, S. B., Gaibulloev, K., \& Sandler, T. (2011). Terrorist group survival: ideology, tactics, and base of operations. Public Choice, 149(3-4), 441.

Bloom, M. (2012). Bombshell: Women and Terrorism. Philadelphia: University of Pennsylvania Press.

Bloom, M. (2017). Women and terrorism. Oxford Research Encyclopedia of Politics. https://oxfordre.com/politics/view/10.1093/ acrefore/9780190228637.001.0001/acrefor e-9780190228637-e-124?mediaType=Article

Blumstein, A., Cohen, J., and Farrington, D.P. (1988). Criminal career research: Its value for criminology. Criminology 26,1-35.

Boncio, A. (2017). Italian Foreign terrorist fighters: a quantitative analysis of radicalization risk factors. In: Niglia, A., Al Sabaileh, A., \& Hammad, A. (eds.). Countering Terrorism, Preventing Radicalization and Protecting Cultural Heritage, pp.133-40.

Borum, R. (2015). Assessing risk for terrorism involvement. Journal of Threat Assessment and Management, 2(2), 63-87.

Bouffard, L. A. (2003). Examining the relationship between military service and criminal behavior during the Vietnam Era: A research note. Criminology, 41, 491-510.

Bouffard, L. A., \& Laub, J. H. (2004). Jail or the Army: Does military service facilitate desistance from crime? In: Maruna, S., \& Immarigeon, R. (eds.). After Crime and Punishment: Pathways to Offender Reintegration. Portland, OR:Willan, pp. 129-151.

Bove, V., \& Böhmelt, T. (2016). Does immigration induce terrorism? Journal of Politics, 78(2), 572-588.

Braithwaite, A., \& Johnson, S. D. (2012). Space-time modeling of insurgency and counterinsurgency in Iraq. Journal of Quantitative Criminology, 28(1), 31-48.

Braithwaite, A., \& Li, Q. (2007). Transnational terrorism hot spots: Identification and impact evaluation. Conflict Management and Peace Science ,24(4), 281-296.

Brandon, J. (2009). The danger of prison radicalization. CTC Sentinel, 2(12), 1-4.

Breen, C. D. (2014). Group Conflict Theory. The Encyclopedia of Theoretical Criminology. https://onlinelibrary.wiley.com/doi/abs/ 10.1002/9781118517390.wbetc097

Brockhoff, S., Krieger, T., \& Meierrieks, D. (2015). Great expectations and hard times: The (nontrivial) impact of education on domestic terrorism. Journal of Conflict Resolution, 59(7), 1186-1215.

Bruinsma, G. J.N., \& Johnson, S. D. (eds.). (2018). The Oxford handbook of environmental criminology. Oxford University Press.

Burgess E. W. (1936). Protecting the public by parole and by parole prediction. American Institute of Criminal Law and Criminology, 27, 491.

Burgoon, B. (2006). On Welfare and Terror: Social welfare policies and political-economic roots of terrorism. Journal of Conflict Resolution, 50(2), 176-203.

Carson, J.V., Dugan, L,. \& Yang, S.M. (2020). A comprehensive application of rational choice theory: How costs imposed by, and benefits derived from, the U.S. federal government affect incidents perpetrated by the radical eco-movement. Journal of Quantitative Criminology, (3)36, 701-724.

Caruso, R., \& Schneider, F. (2011). The socio-economic determinants of terrorism and political violence in Western Europe (1994-2007). European Journal of Political Economy, 27, 37-S49.

Chenoweth, E. (2013). Terrorism and democracy. Annual Review of Political Science, 16, 355-378. 
Chenoweth, E., \& Dugan, L. (2012). Rethinking Counterterrorism: Evidence from Israel. SSRN Electronic Journal. 1-38. https://doi.org/10.2139/ssrn.1664282.

Chenoweth, E. (2010). Democratic competition and terrorist activity. Journal of Politics, 72(1), 16-30.

Chermak, S., Freilich, J., \& Suttmoeller, M. (2013). The organizational dynamics of far-right hate groups in the United States: Comparing violent to nonviolent organizations. Studies in Conflict and Terrorism, 36(3), 193-218.

Chiricos, T. (1987). Rates of crime and unemployment: An analysis of aggregate research evidence. Social Problems, 34, 187-212.

Choi, S. W., \& Piazza, J. A. (2016). Ethnic groups, political exclusion and domestic terrorism. Defence and Peace Economics, 27(1), 37-63.

Choi, S. W. (2015). Economic growth and terrorism: Domestic, international, and suicide. Oxford Economic Papers, 67(1), 157-181.

Choi, S. W., \& Salehyan, I. (2013). No good deed goes unpunished: Refugees, humanitarian aid, and terrorism. Conflict Management and Peace Science, 30(1), 53-75.

Cilluffo, F. J., Cardash, S. L., \& Whitehead, A. J. (2006). Radicalization: Behind bars and beyond borders. Brown Journal of World Affairs, 13, 113.

Clarke, R.V., \&, Newman, G.R. (2006). Outsmarting the Terrorists. Westport, CT: Praeger Security International.

Cliff, C., \& First, A. (2013). Testing for contagion/diffusion of terrorism in state dyads. Studies in Conflict and Terrorism, 36(4), 292-314.

Coccia, M. (2018). The relation between terrorism and high population growth. Journal of Economics and Political Economy, 5(1), 84-104.

Cocozza, J.J., Melick, M. E., \& Steadman, H.J. (1978). Trends in violent crime among ex-mental patients. Criminology, 16, 317-34.

Cooley, J.K. (2002). Unholy Wars: Afghanistan, America and International Terrorism. Sterling, VA: Pluto Press.

Corner, E., \& Gill, P. (2020). Psychological distress, terrorist involvement and disengagement from terrorism: A sequence analysis approach. Journal of Quantitative Criminology, (3)36, 499-526.

Corner, E., Gill, P., \& Mason, O. (2016). Mental health disorders and the terrorist: A research note probing selection effects and disorder prevalence. Studies in Conflict and Terrorism, 39, 560-68.

Craig, C. M., Overbeek, R. W. \& Niedbala, E. M. (2019). A global analysis of temperature, terrorist attacks, and fatalities. Studies in Conflict and Terrorism, 17, 1-13.

Danzell, O. E., \& Zidek, S. (2013). Does counterterrorism spending reduce the incidence and lethality of terrorism? A quantitative analysis of 34 countries. Defense and Security Analysis, 29(3), 218-233.

DeLisi, M., Neppl, T.K., Lohman, B.J., Vaughn, M.G., \& Shook, J.J. (2013). Early starters: Which type of criminal onset matters most for delinquent careers? Journal of Criminal Justice, 41, 12-17.

Desmarais, S. L., Simons-Rudolph, J., Brugh, C. S., Schilling, E., \& Hoggan, C. (2017). The state of scientific knowledge regarding factors associated with terrorism. Journal of Threat Assessment and Management, 4(4), 180-209.

Dev, P., \& Grabiszewski, K. (2019). More is not always better: The case of counterterrorism security. Journal of Conflict Resolution, 63(8), 1923-1938.

Department of Homeland Security, Office of Intelligence and Analysis. (2009). Rightwing Extremism: Current Economic and Political Climate Fueling Resurgence in Radicalization and Recruitment. Washington, DC: United States Government.
Dugan, L., \& Chenoweth, E. (2012). Moving beyond deterrence: The effectiveness of raising the expected utility of abstaining from terrorism in Israel. American Sociological Review, 77(4), 597-624.

Easson, J.J., \& Schmid, A. P. (2011). 250+ Academic, Governmental and Intergovernmental Definitions of Terrorism. In: Schmid, A. P. (ed.). The Routledge Handbook of Terrorism Research. New York and London: Routledge, pp. 99-200.

Eder, F. \& Senn, M. (eds.). (2008). Europe and transnational terrorism: Assessing threats and countermeasures. Baden Baden, Germany: Nomos.

Egger, C., \& Magni-Berton, R. (2019). The role of Islamist ideology in shaping Muslim believers' attitudes toward terrorism: Evidence from Europe. Studies in Conflict \& Terrorism, 21, 1-24.

Enders, W., Sandler, T. \& Gaibulloev, K. (2011). Domestic versus transnational terrorism: Data, decomposition, and dynamics. Journal of Peace Research, 48(3), 319-337.

Eubank, W., \& Weinberg, L. (2001). Terrorism and democracy: Perpetrators and victims. Terrorism and Political Violence, 13(1), 155-164.

Ezcurra, R. \& Palacios, D. (2016). Terrorism and spatial disparities: Does interregional inequality matter? European Journal of Political Economy, 42, 60-74.

Esty, D.C., Goldstone, J.A., Gurr, T.R., Surko, P., \& Unger, A.N. (1995). State failure task force report. McLean, VA: Science Applications International Corporation.

Farrington, D.P. (2003). Developmental and life-course criminology: Key theoretical and empirical issues-The 2002 Sutherland Award Address. Criminology, 41, 221-25.

Farrington, D.P. (1998). Predictors, causes, and correlates of male youth violence. Crime and Justice, (1)24, 421-75.

Federal Bureau of Investigation (2008). White Supremacist Recruitment of Military Personnel since 9/11. Washington, DC: U.S. Government Printing Office.

Forrester, A. C., Powell, B., Nowrasteh, A., \& Landgrave, M. (2019). Do immigrants import terrorism? Journal of Economic Behavior \& Organization, 166, 529-543.

Forst, B., Greene, J. R., \& Lynch, J. P. (2011). Criminologists on Terrorism and Homeland Security. New York: Cambridge University Press.

Foster, D. M., Braithwaite, A., \& Sobek, D. (2013). There can be no compromise: Institutional inclusiveness, fractionalization and domestic terrorism. British Journal of Political Science, pp. 541-717.

Freilich, J.D., Gruenewald, J., \& Mandala, M. (2019) Situational crime prevention and terrorism: An assessment of 10 years of research. Criminal justice policy review, 30(9), 1283-311.

Freilich, J., \& LaFree, G. (2015). Criminology theory and terrorism. Terrorism and Political Violence, 27, 1-8.

Freilich, J. D., Adamczyk, A., Chermak, S. M., Boyd, K. A., \& Parkin, W. S. (2015). Investigating the applicability of macro-level criminology theory to terrorism: A county-level analysis. Journal of Quantitative Criminology, 31(3), 383-411.

Freilich, J. D., Chermak, S. M., Belli, R., Gruenewald, J., \& Parkin, W. S. (2014). Introducing the United States Extremist Crime Database (ECDB). Terrorism and Political Violence, 26(2), 372-384.

Freytag, A., Krüger, J. J., Meierrieks, D. \& Schneider, F. (2011). The origins of terrorism: Cross-country estimates of socio-economic determinants of terrorism. European Journal of Political Economy, 27, S5-S16.

Gaibulloev, K., Piazza, J. A., \& Sandler, T. (2017). Regime types and terrorism. International Organization, 71(3), 491-522. 
Gendreau, P., Little, T., \& and Goggin, C. (1996). A meta-analysis of the predictors of adult offender recidivism: What works! Criminology, 34, 575-608.

Gil-Alana, L. A., \& Barros, C. P. (2010). A note on the effectiveness of national anti-terrorist policies: Evidence from ETA. Conflict Management and Peace Science, 27(1), 28-46.

Gill, P., \& Corner, E. (2016). Lone-actor terrorist target choice. Behavioral Sciences \& the Law, 34, 693-705.

Gill, P. (2015). Toward a scientific approach to identifying and understanding indicators of radicalization and terrorist intent: Eight key problems. Journal of Threat Assessment and Management, 2(3-4), 187-191.

Gill, P., Horgan, J. \& Deckert, P. (2014). Bombing alone: tracing the motivations and antecedent behaviors of lone-actor terrorists. Journal of Forensic Sciences, 59(2), 425- 435.

Goldstone, J. A., Bates, R. H., Epstein, D. L., Gurr, T. R., Lustik, M. B., Marshall, M. G., Ulfelder, J., \& Woodward, M. (2010). A global model for forecasting political instability. American Journal of Political Science, 54(1), 190-208.

Gries, T., Krieger, T., \& Meierrieks, D. (2011). Causal linkages between domestic terrorism and economic growth. Defence and Peace Economics, 22(5), 493-508.

Gruenewald, J., \& Pridemore, W. A. (2012). A comparison of ideologically-motivated homicides from the new extremist crime database and homicides from the supplementary homicide reports using multiple imputation by chained equations to handle missing values. Journal of Quantitative Criminology, 28(1), 141-162.

Gruenewald, J., Chermak, S., \& Freilich, J. D. (2013a). Distinguishing »loner « attacks from other domestic extremist violence. Criminology and Public Policy, 12(1), 65-91.

Gruenewald, J., Chermak, S., \& Freilich, J. D. (2013b). Far-Right lone wolf homicides in the United States. Studies in Conflict and Terrorism, 36(12), 1005-1024.

Hafez M. (2008). Radicalization in the Persian Gulf: assessing the potential of Islamist militancy in Saudi Arabia and Yemen. Dynamics of Asymmetric Conflict, 1, 6-24.

Hafez, M. \& Mullins, C. (2015). The radicalization puzzle: A theoretical synthesis of empirical approaches to homegrown extremism. Studies in Conflict \& Terrorism, 38(11), 958-975.

Hamm, M.S. (1993). American skinheads: The criminology and control of hate crime. ABC-CLIO.

Hansen-Lewis, J. \& Shapiro, J. N. (2015). Understanding the Daesh economy. Perspectives on Terrorism, 9(4), 142-155.

Hasson, Y., Tamir, M., Brahms, K.S., Cohrs, J.C., \& Halperin, E. (2018). Are liberals and conservatives equally motivated to feel empathy toward others? Personality and Social Psychology Bulletin, 44(10), 1449-59.

Hasisi, B., Carmel, T., \& Wolfowicz, M. (2020a). Crime and terror: Examining criminal risk factors for terrorist recidivism. Journal of Quantitative Criminology, (3)36, 449-472.

Hasisi, B., Perry, S., Ilan, Y., \& Wolfowicz, M. (2020b). Concentrated and close to home: the spatial clustering and distance decay of lone terrorist vehicular attacks. Journal of Quantitative Criminology, 1-39.

Henne, P.S. (2012). The ancient fire: Religion and suicide terrorism. Terrorism and Political Violence, 24(1),38-60.

Hewitt, C., \& Kelley-Moore, J. (2009). Foreign fighters in Iraq: a cross-national analysis of Jihadism. Terrorism and Political Violence, 21(2), 211-220.
Hewitt, C. (2003). Understanding Terrorism in America: From the Klan to Al Qaeda. New York: Routledge.

Hirschi, T. (1969). Causes of Delinquency. Berkeley: University of California Press.

Hitlan, R. T., Carillo, K., Zárate, M. A. \& Aikman, S. N. (2007). Attitudes toward immigrant groups and the September 11 terrorist attacks. Peace and Conflict, 13(2), 135-152.

Hoffman, B. (2006). Inside Terrorism. New York: Columbia University Press.

Horgan, J. (2008). From profiles to pathways and roots to routes: Perspectives from psychology on radicalization into terrorism. The ANNALS of the American Academy of Political and Social Science, 618(1), 80-94.

Hosenhall, M. (2018, May 16). U.S. has more than 2,000 probes into potential or suspected terrorists: FBI Director. Reuters. https://www.reuters.com/article/us-usa-fbi-wray/us-has-morethan-2000-probes-into- potential-or-suspected-terrorists-fbidirector-idUSKCN1IH341

Hough, M., Jackson, J., Bradford, B., Myhill, A. \& Quinton, P. (2010). Procedural justice, trust, and institutional legitimacy. Policing: A Journal of Policy and Practice, 4 (3), 203-210.

Hsu, H.Y., Vásquez, B.E., \& McDowall D. (2018). A time-series analysis of terrorism: Intervention, displacement, and diffusion of benefits. Justice Quarterly, 35(4), 557-83.

Ja’sko, K., LaFree, G. \& Kruglanski, A. (2017). Quest for significance and violent extremism: The case of domestic radicalization. Political Psychology, 38, 815-31.

Jensen, M. A., Seate, A. A., \& James, P. A. (2018). Radicalization to Violence: A Pathway Approach to Studying Extremism. Terrorism and Political Violence, 32(5), 1067-1090.

Johnson, B. (2012). Classified multilevel models: An application to the criminal case processing of indicted terrorists. Journal of Quantitative Criminology, 28(1), 163-189.

Jones, C.R. (2014) Are prisons really schools for terrorism? Challenging the rhetoric on prison radicalization. Punishment and Society, 16(1):74-103.

Jugl, I., Lösel, F., Bender, D., \& King, S. (2020). Psychosocial prevention programs against radicalization and extremism: a meta-analysis of outcome evaluations. European Journal of Psychology Applied to Legal Context, 13(1), 37-46.

Juergensmeyer, M. (2003). Terror in the Mind of God: The Global Rise of Religious Violence. Berkeley: University of California Press.

Juergensmeyer, M. (2016). Terror in the Mind of God: The Global Rise of Religious Violence. Oxford Research Encyclopedia of Religion. Oxford University Press.

Kepel, G. (2006). Jihad: The Trail of Political Islam. London: IB Tauris. Kirk, D. S. (2012). Residential change as a turning point in the life course of crime: Desistance or temporary cessation? Criminology, 50, 329-58.

Kittrie, N. N. (1978). A new look at political offenses and terrorism. In: Livingston, M. H., Kress, L. B., \& Wanek, M.G. (eds.). International Terrorism in the Contemporary World. Westport, CT: Greenwood, pp. 354-375.

Klausen, J. (2015). Tweeting the jihad: Social media networks of Western foreign fighters in Syria and Iraq. Studies in Conflict \& Terrorism, 38, 1-22.

Klausen, J., Morrill, T., \& Libretti, R. (2016). The terrorist age-crime curve: An analysis of American Islamist terrorist offenders and age-specific propensity for participation in violent and nonviolent incidents. Social Science Quarterly, 97(1), 19-32. 
Klein, B. R., Gruenewald, J., \& Smith, B. L. (2017). Opportunity, group structure, temporal patterns, and successful outcomes of farright terrorism incidents in the United States. Crime and Delinquency, 63(10), 1224-1249.

Kluch, S. P. \& Vaux, A. (2016). The non-random nature of terrorism: An exploration of where and how global trends of terrorism have developed over 40 years. Studies in Conflict and Terrorism, 39(12), 1031-1049.

Koeppel, M. D., Rhineberger-Dunn, G. M., \& Mack, K. Y. (2015). Cross-national homicide: A review of the current literature. International Journal of Comparative and Applied Criminal Justice, 39(1), 47-85.

Krieger, T., \& Meierrieks, D. (2012). Does Income Inequality Lead to Terrorism? SSRN Electronic Journal. https://doi.org/10.2139/ ssrn.1647178.

Krueger, Alan B. (2007). What Makes a Terrorist: Economics and the Roots of Terrorism. Princeton, NJ: Princeton University Press.

Krueger, A. B., \& Laitin, D. D. (2008). Kto kogo?: A cross-country study of the origins and targets of terrorism. Terrorism, Economic Development, and Political Openness, 5, 148-173.

Krueger, Alan B., \& Malěckov, J. (2003). Education, poverty and terrorism: Is there a causal connection? Journal of Economic Perspectives, 17, 119-44.

Kruglanski, A. W., Gelfand, M. J., Bélanger, J. J., Sheveland, A., Hetiarachchi, M., \& Gunaratna, R. (2014). The psychology of radicalization and deradicalization: How significance quest impacts violent extremism. Political Psychology, 35, 69-93.

Kruglanski, A. W., Chen, X., Dechesne, M., Fishman, S., \& Orehek, E. (2009). Fully committed: Suicide bombers' motivation and the quest for personal significance. Political Psychology, 30(3), 331-357.

Kurrild-Klitgaard, P., Justesen, M. K., \& Klemmensen, R. (2006). The political economy of freedom, democracy and transnational terrorism. Public Choice, 128(1-2), 289-315.

LaFree, G. (2021). Progress and obstacles in the internationalization of criminology. International Criminology, 1(1):58-69.

LaFree, G. (2019). The evolution of terrorism event databases. In: Chenoweth, E., Gofas, A., English, R., \& Kalyvas, S. (eds.). Handbook on Terrorism. New York: Oxford University Press, pp. 50-68.

LaFree, G., \& Ackerman, G. (2009). The empirical study of terrorism: Social and legal research. Annual Review of Law and Social Science, 5, 347-374.

LaFree, G., \& Bersani, B. E. (2014). County-level correlates of terrorist attacks in the United States. Criminology and Public Policy, 13 (3), 455-481.

LaFree, G. \& Dugan, L. (2004). How does studying terrorism compare to studying crime? In: DeFlem, M. (ed.), Terrorism and Counter-Terrorism: Criminological Perspectives Sociology of Crime, Law and Deviance, vol. 5. London: Elsevier, pp. 53-74.

LaFree, G. \& Dugan, L. (2007). Introducing the Global Terrorism Database. Terrorism and Political Violence, 19(2), 181-204.

LaFree, G., \& Dugan, L. (2009). Research on terrorism and countering terrorism. Crime and Justice, 38, 413-477.

LaFree, G., Dugan, L., \& Korte, R. (2009). The impact of British counterterrorist strategies on political violence in Northern Ireland: Comparing deterrence and backlash models. Criminology, 47(1), 17-45.

LaFree, G., Dugan, L., \& Miller, E. (2015). Putting Terrorism in Context: Lessons from the Global Terrorism Database. New York: Routledge.
LaFree, G., Dugan, L., Xie, M., \& Singh, P. (2012). Spatial and temporal patterns of terrorist attacks by ETA 1970 to 2007. Journal of Quantitative Criminology, (1)28, 7-29.

LaFree, G., \& Freilich, J. (2012). Editor's introduction: Quantitative approaches to the study of terrorism Journal of Quantitative Criminology, (1)28, 1-5.

LaFree, G., Jensen, M. A., James, P. A., \& Safer-Lichtenstein, A. (2018). Correlates of Violent Political Extremism in the United States. Criminology, 56(2), 233-268.

LaFree, G., Jiang, B., \& Porter, L. (2020). Prison and Violent Political Extremism in the United States. Journal of Quantitative Criminology, 36(3), 1-26.

LaFree, G., Weerman, F., \& Bjleveld, C. (2020). Editor's introduction: Terrorism and violent extremism. Journal of Quantitative Criminology, 36(3), 399-405.

LaFree, G., Xie, M., \& Matanock, A. M. (2018). The contagious diffusion of worldwide terrorism: Is it less common than we might think? Studies in Conflict and Terrorism, 41(4), 261-280.

LaFree, G. Yanez, Y. (forthcoming). Criminological perspectives on extremist radicalization and mobilization. In: Busher, J., Malikki, L. \& Marsden, S. (eds.). Radcialisation and Countering Radicalisation. London: Routledge.

Lai, B. (2007). »Draining the Swamp«: An empirical examination of the production of international terrorism, 1968-1998. Conflict Management and Peace Science, 24(4), 297-310.

Lattimore, P. K., Visher, C. A., \& Linster, R. L. (1995). Predicting rearrest for violence among serious youthful offenders. Journal of Research in Crime and Delinquency, 32(1), 54-83.

Laub, J. H., \& Sampson, R. J. (1993). Turning points in the life course: Why change matters to the study of crime. Criminology, 31, 301-25.

Li, Q. (2005). Does democracy promote or reduce transnational terrorist incidents? Journal of Conflict Resolution, 49(2), 278-297.

Li, Q., \& Schaub, D. (2004). Economic globalization and transnational terrorism: A pooled time-series analysis. Journal of Conflict Resolution, 48(2), 230-258.

Lincoln, B. (2010). Holy Terrors: Thinking About Religion After September 11. Chicago: University of Chicago Press.

Ljujic, V., van Prooijen, J. W., \& Weerman, F. (2017). Beyond the crime-terror nexus: socio-economic status, violent crimes and terrorism. Journal of Criminological Research, Policy and Practice, 3(3), 158-172.

Loeber, R., \& Le Blanc, M. (1990). Toward a developmental criminology. In: ed. Tonry, M. (eds.). Crime and Justice: A Review of Research. Chicago, IL: University of Chicago Press, vol. 12, pp. 375-473.

Lösel, F., King, S., Bender, D., \& Jugl, I. (2018). Protective factors against extremism and violent radicalization: A systematic review of research. International Journal of Developmental Science, 12(1-2), 89-102.

Lum, C., \& Kennedy, L. W. (eds.) (2012). Evidence-Based Counterterrorism Policy. New York: Springer.

Lum, C., Kennedy, L. W., \& Sherley, A. (2006). Are counter-terrorism strategies effective? the results of the Campbell systematic review on counter-terrorism evaluation research. Journal of Experimental Criminology, 2(4), 489-516.

Lyons, C. J., Vélez, M. B., \& Santoro, W. A. (2013). Neighborhood immigration, violence, and city-level immigrant political opportunities. American Sociological Review, 78(4), 604-632. 
Marbach, M., \& Ropers, G. (2018). Not in My Backyard: Do Increases in Immigration Cause Political Violence? Chicago. SSRN Electronic Journal. http://dx.doi.org/10.2139/ssrn.3310352.

Marchment, Z., \& Gill, P. (2019). Modelling the spatial decision making of terrorists: The discrete choice approach. Applied Geography, 104, 21-31.

Marsden, S. V. (2016). A social movement theory typology of militant organisations: contextualising terrorism. Terrorism and Political Violence, 28(4), 750-773.

Masters, D., \& Hoen, P. (2012). State legitimacy and terrorism. Democracy and Security, 8(4), 337-357.

McAlexander, R. J. (2020). How are immigration and terrorism related? An analysis of right-and left-wing terrorism in Western Europe, 1980-2004. Journal of Global Security Studies, 5(1), 179-195.

McCauley, C., \& Moskalenko, S. (2011). Friction: How Radicalization Happens to Them and Us. New York, NY: Oxford University Press.

McMillan, C. Felmlee, D., \& Braines, D. (2020). Dynamic patterns of terrorist networks: Efficiency and security in the evolution of eleven Islamic extremist attack networks. Journal of Quantitative Criminology, (3)36, 559-581.

Mendelsohn, B. (2011). Foreign fighters-recent trends. Orbis, 55(2), 189-202.

Miller E. (2012). Patterns of onset and decline among terrorist organizations. Journal of Quantitative Criminology, 28(1), 77-101.

Mills, C., Freilich, J., Chermak, S., Holt. T., \& LaFree, G. (2019). Social learning and social control in the off- and on-line pathways to hate crime and terrorist violence. Studies in Conflict and Terrorism, 44, 1-29.

Moghadam A. (2006). The roots of suicide terrorism: a multi-causal approach. In: Pedhazur, A. (ed.). Root Causes of Suicide Terrorism: The Globalization of Martyrdom. London: Routledge, pp. 81-107.

Monahan, J. (2017). The Individual Risk Assessment of Terrorism. In: LaFree, G., \& Freilich, J. D. (eds.). The Handbook of the Criminology of Terrorism, pp. 520-534.

Monahan, J., \& Skeem, J. L. (2015). Risk Assessment in criminal sentencing. Virginia Public Law and Legal Theory Research Paper, No. 53. SSRN Electronic Journal. https://papers.ssrn.com/sol3/ papers.cfm?abstract_id=2662082.

Morin, R. (2014). Conflict Theory. In: Miller, J. M. (2014). The Encyclopedia of Theoretical Criminology. https://onlinelibrary.wiley. com/doi/abs/10.1002/9781118517390.wbetc124.

Morris, N. A., \& Slocum, L. A. (2012). Estimating country-level terrorism trends using group-based trajectory analyses: Latent class growth analysis and general mixture modeling. Journal of Quantitative Criminology, 28(1), 103-139.

Mulcahy, E., Merrington, S., \& Bell, P.J. (2013) The radicalisation of prison inmates: a review of the literature on recruitment, religion and prisoner vulnerability. Journal of Human Security, 9(1), 4-14.

Murphy, K., Bradford, B., \& Jackson, J. (2016). Motivating compliance behavior among offenders: Procedural justice or deterrence? Criminal Justice and Behavior, 43(1), 102-118.

Nemeth, S. C., Mauslein, J. A., \& Stapley, C. (2014). The primacy of the local: Identifying terrorist hot spots using geographic information systems. The Journal of Politics, 76(2), 304-317.

Nettler, G. (1984). Explaining Crime. New York: McGraw-Hill Ryerson. Neumann, P. R. (2013). The trouble with radicalization. International Affairs, 89(4), 873-893.
Newman, E. (2007). Weak states, state failure, and terrorism. Terrorism and Political Violence, 19(4), 463-488.

Nijboer, M. (2012). A review of lone wolf terrorism: The need for a different approach. Social Cosmos, 3, 33-9.

Nivette, A. E. (2011). Cross-national predictors of crime: A meta-analysis. Homicide Studies, 15(2), 103-131.

Nivette, A., Eisner, M., \& Ribeaud, D. (2017). Developmental predictors of violent extremist attitudes: A test of general strain theory. Journal of Research in Crime and Delinquency, 54(6), 755-90.

Onat, I. (2019). An analysis of spatial correlates of terrorism using risk terrain modeling. Terrorism and Political Violence, 31(2), 277-298.

Ortbals, C.D., \& Poloni-Staudinger, L.M. (2018). Gender and political violence: Women changing the politics of terrorism. Switzerland: Springer.

Pape, R. (2005). Dying to Win: The Strategic Logic of Suicide Terrorism. New York, NY: Random House Publishing Group.

Perry, S. (2020). The application of the »law of crime concentration« to terrorism: The Jerusalem case study. Journal of Quantitative Criminology, 36(3), 583-605.

Perry, S., Apel, R., Newman, G.R., \& Clarke, R.V. (2017). The situational prevention of terrorism: an evaluation of the Israeli West Bank barrier. Journal of Quantitative Criminology, 33(4): 727-51.

Piazza, J. A. \& LaFree, G. (2019). Islamist terrorism, diaspora links and casualty rates. Perspectives on Terrorism, 13(5), 2-21.

Piazza, J. A. (2013). Regime Age and Terrorism: Are New Democracies Prone to Terrorism? International Interactions, 39(2), 246-263.

Piazza, J. A. (2012). Types of minority discrimination and terrorism. Conflict Management and Peace Science, 29(5), 521-546.

Piazza, J. A. (2011). Poverty, minority economic discrimination, and domestic terrorism. Journal of Peace Research, 48(3), 339-353.

Piazza, J.A. (2009) Is Islamist terrorism more dangerous? An empirical study of group ideology, organization, and goal structure. Terrorism and Political Violence 21(1), 62-88.

Piazza, J. A. (2008a). Do democracy and free markets protect us from terrorism? International Politics, 45(1), 72-91.

Piazza, J. A. (2008b). Incubators of terror: Do failed and failing states promote transnational terrorism? International Studies Quarterly, 52(3), 469-488.

Piazza, J. A. (2006). Rooted in poverty? Terrorism, poor economic development, and social cleavages. Terrorism and Political Violence, 18, 159-77.

Plümper, T., \& Neumayer, E. (2010). Model specification in the analysis of spatial dependence. European Journal of Political Research, 49(3), 418-442.

Porter, M. D. \& White, G. (2010). Self-exciting hurdle models for terrorist activity. Annals of Applied Statistics, 4(1), 106-124.

Post, J.M., Ruby, K.G., Shaw, E.D. (2002). The radical group in context: An integrated framework for the analysis of group risk for terrorism. Studies in Conflict and Terrorism, 25(2), 73-100.

Price, G. N., \& Elu, J. U. (2016). Global warming and cross-state Islamist terrorism in Nigeria. Department of Economics, Morehouse College, Atlanta GA, 30314.

PROTON (2020). Project Proton. https://www.projectproton.eu/ about/

Pyrooz, D., LaFree, G., Decker, S., \& James, P. (2017). Cut from the same cloth? Comparing gangs and violent political extremists. Justice Quarterly, 35(1), 1-32. 
Python, A., Brandsch, J., \& Tskhay, A. (2017). Provoking local ethnic violence-A global study on ethnic polarization and terrorist targeting. Political Geography, 58, 77-89.

Python, A., Illian, J., Jones-Todd, C., \& Blangiardo, M. (2016). A Bayesian Approach to Modelling Fine-Scale Spatial Dynamics of Non-State Terrorism: World Study, 2002-2013. ArXiv preprints. https://arxiv.org/abs/1610.01215

Russell CA, \& Miller BH. (1977). Profile of a terrorist. Military Review, 57, 21-34.

Sageman, M. (2014). The stagnation in terrorism research. Terrorism and Political Violence, 26(4), 565-580.

Sageman, M. (2004). Understanding Terror Networks. Philadelphia: University of Pennsylvania Press.

Sampson, R. J., \& Lauritsen, J. L. (1994). Violent victimization and offending: Individual-, situational-, and community-level risk factors. In: Miczek, K.A., Reiss, A.J., Roth, J.A. (eds.) Panel on the understanding and preventing violence, Volume 3. National Academy Press

Sampson, R. J., Raudenbush, S. W., \& Earls, F. (1997). Neighborhoods and violent crime: A multilevel study of collective efficacy. Science, 277(5328), 918-924.

Sarma, K. M. (2017). Risk assessment and the prevention of radicalization from nonviolence into terrorism. American Psychologist, 72(3), 278-288.

Savun, B., \& Phillips, B. J. (2009). Democracy, foreign policy, and terrorism. Journal of Conflict Resolution, 53(6), 878-904.

Schmid, A.P. (2014). Violent and non-violent extremism: Two sides of the same coin. ICCT Research Paper. https://www.icct.nl/ download/file/ICCT-Schmid-Violent-Non-Violent-ExtremismMay-2014.pdf

Schmid AP, \& Jongman AJ. (1988). Political Terrorism: A New Guide to Actors, Authors, Concepts, Databases, Theories and Literature. Amsterdam: North-Holland.

Schuurman, B. (2020). Research on Terrorism, 2007-2016: A Review of Data, Methods, and Authorship. Terrorism and Political Violence, 32(5), 1011-1026.

Schwarzenbach, A., \& LaFree, G. (2020). Political legitimacy and worldwide terrorist attacks, 1970-2017. APSA Preprints. doi: 10.33774/apsa-2020-19hn3.

Schwarzenbach, A., \& Baier, D. (forthcoming). Political legitimacy and political extremism. Evidence from a Swiss school survey. Unpublished manuscript.

Semmelbeck, J., \& Besaw, C. (2020). Exploring the determinants of crime-terror cooperation using machine learning. Journal of Quantitative Criminology, (3)36, 527-558.

Shapiro, Jacob N. (2013). The Terrorist's Dilemma: Managing Violent Covert Organizations. Princeton, NJ: Princeton University Press.

Shaw, C. R., \& McKay, H. D. (1942). Juvenile delinquency and urban areas. Chicago: University of Chicago Press.

Silke, A. (2009). Contemporary terrorism studies: issues in research. In: Jackson, R., Smyth, M. B., \& Gunning, J. (Eds.). Critical Terrorism Studies: A new research agenda. Abingdon: Routledge.

Silke, A. (2001). The devil you know: Continuing problems with research on terrorism. Terrorism and Political Violence 13(4), 1-14.

Simi, P., Karyn S., \& Bubolz, B. (2016). Narratives of childhood adversity and adolescent misconduct as precursors to violent extremism: A lifecourse criminological approach. Journal of Research in Crime and Delinquency, 53, 536-63.
Simpson, M. (2014). Terrorism and Corruption. International Journal of Sociology, 44(2), 87-104. https://doi.org/10.2753/ij s0020-7659440204.

Sjoberg, L., \& Gentry, C.E. (eds.) (2011). Women, gender and terrorism. Athens, GA: University of Georgia Press.

Smith, B.L. (1994). Terrorism in America: Pipe bombs and pipe dreams. Albany: SUNY Press.

Smith, M.D., Devine, J.A., \& Sheley, J.F. (1992). Crime and unemployment: Effects across age and race categories. Sociological Perspectives, 35, 551-72.

Spaaij, R. (2011). Understanding Lone Wolf Terrorism: Global Patterns, Motivations and Prevention. New York: Springer Science \& Business Media.

Speckhard, A., \& Akhmedova, K. (2006). Black widows: The Chechen female suicide terrorists. In: Schweitzer, Y. (ed.) Female Suicide Bombers: Dying for Equality. Tel Aviv, Israel: Jaffee Center for Strategic Studies, pp. 63-80.

Steadman, H. J., \& Felson, R. B. (1984). Self-reports of violence. Criminology, 22, 321-42.

Stern, J. (2002). Dreaded risks and the control of biological weapons. International Security, 27(3), 89-123.

Sykes, B. L., \& Pettit, B. (2014). Mass incarceration, family complexity, and the reproduction of childhood disadvantage. The Annals of the American Academy of Political and Social Science, 654(1), 127-149.

Sweeten, G., Piquero, A. R., \& Steinberg, L. (2013). Age and the explanation of crime, revisited. Journal of Youth and Adolescence, 42, 921-38.

Tarrow, S. G. (2011). Power in Movement: Social Movements and Contentious Politics (3 edition). Cambridge, New York: Cambridge University Press.

Turk, A. T. (2004). Sociology of terrorism. Annual Review of Sociology, 30, 271-86.

Turk A. 1982. Political Criminality: The Defiance and Defense of Authority. Beverly Hills, CA: Sage.

Tyler, T. R. (1990). Why people obey the law. New Haven, CT: Yale Univ. Press.

Uggen, C. (2000). Work as a turning point in the life course of criminals: A duration model of age, employment, and recidivism. American Sociological Review, 67, 529-46.

Useem, B., \& Clayton, O. (2009). Radicalization of U.S. prisoners. Criminology and Public Policy, 8, 561-92.

Van Hiel, A., Onraet, E., Bostyn, D. H., Stadeus, J., Haesevoets, T., Van Assche, J., \& Roets, A. (2020). A meta-analytic integration of research on the relationship between right-wing ideological attitudes and aggressive tendencies. European Review of Social Psychology, 31(1), 183-221.

Van Leyenhorst, M., \& Andreas, A. (2017). Dutch suspects of terrorist activity: A study of their biographical backgrounds based on primary sources. Journal for Deradicalization, 12, 309-344.

Varaine, S. (2019). Revisiting the economics and terrorism nexus: Collective deprivation, ideology and domestic radicalization in the U.S. (1948-2016). Journal of Quantitative Criminology, (3) 36, 667-699.

Victoroff, J. (2005). The mind of the terrorist: a review and critique of psychological approaches. Journal of Conflict Resolution, 49(1), 3-42.

Wade, S. J., \& Reiter, D. (2007). Does democracy matter? Regime type and suicide terrorism. Journal of Conflict Resolution, 51(2), 329-348. 
Warr, M. (1998). Life course transitions and desistance from crime. Criminology, 36, 183-216.

Warr, M. (2002). Companions in Crime: The Social Aspects of Criminal Conduct. Cambridge, England: Cambridge University Press.

Warr, M., and Stafford, M. (1991). The influence of delinquent peers: What they think or what they do? Criminology, 29, 851-66.

Warr, M. (1998). Life-course transitions and desistance from crime. Criminology, 36(2), 183-216.

Weenink, A. W. (2015). Behavioral problems and disorders among radicals in police files. Perspectives on Terrorism, 9(2), 17-33.

Western, B. (2002) The impact of incarceration on wage mobility and inequality. American Sociological Review, 67(4), 526-546.

White, G., Ruggeri, F., \& Porter, M. D. (2016). Modelling the Proliferation of Terrorism via Diffusion and Contagion. arXiv preprint. htt ps://arxiv.org/abs/1612.02527

Wikstrom, P.O.H. (2014). Why crime happens: A situational action theory. In: Manzo, G. (ed.). Analytical Sociology: Action and Networks. Chichester: John Wiley, pp. 74-94.

Wikström, P. O. H., \& Bouhana, N. (2017). Analyzing radicalization and terrorism: A situational action theory. In: LaFree, G., \& Freilich, J. (eds.). The Handbook of the Criminology of Terrorism. New York: Wiley Blackewll. (Pp. 175-186).
Wilkenfeld, J. (2008). Unstable states and international crises. In: Hewitt, J. Wilkenfeld, J., \& Gurr, TR (ed.). Peace and Conflict,. Boulder, CO: Paradigm, pp. 67-78.

Wilson, M. C., \& Piazza, J. A. (2013). Autocracies and terrorism: Conditioning effects of authoritarian regime type on terrorist attacks. American Journal of Political Science, 57(4), 941-955.

Wolfowicz, M., Litmanovitz, Y. \& Hasisi, B. (2020). A Field-wide systematic review and meta-analysis of putative risk and protective factors for radicalization outcomes. Journal of Quantitative Criminology, 36(3), 449-472.

Zaal, M. P., Laar, C. V., Ståhl, T., Ellemers, N., \& Derks, B. (2011). By any means necessary: The effects of regulatory focus and moral conviction on hostile and benevolent forms of collective action. British Journal of Social Psychology, 50(4), 670-689.

Zedalis, D. D. (2004). Female Suicide Bombers. Carlisle, PA: Strategic Studies Institute, U. S. Army War College. 